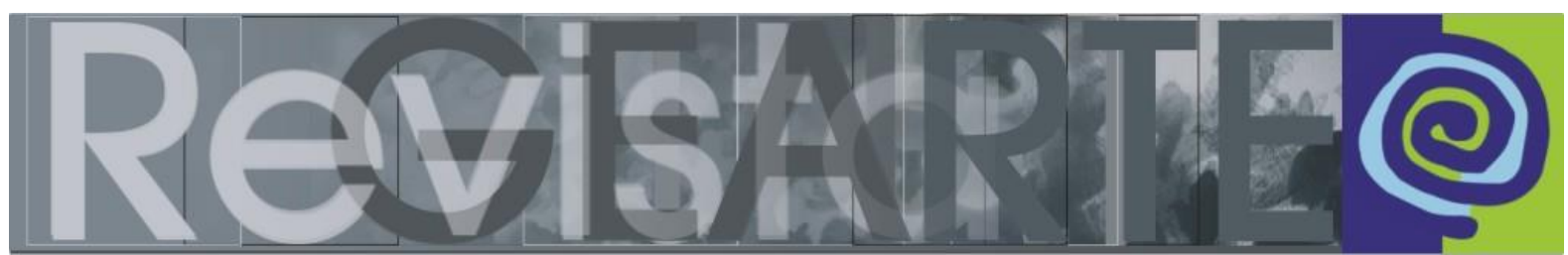

ISSN 2357-9854

\title{
Ensaio Visual: Com quantas janelas? Homenagem a Ana Mae Barbosa
}

\author{
Umbelina Barreto (Universidade Federal do Rio Grande do Sul - UFRGS, \\ Porto Alegre/RS, Brasil)
}

\begin{abstract}
RESUMO - Ensaio Visual: Com quantas janelas? Homenagem a Ana Mae Barbosa - Nós tentamos fazer uma homenagem a Ana Mae Barbosa partindo da poética de sua própria imagem em ação, mas isso não é uma tarefa fácil, principalmente, se pensarmos em como ela tem dedicado a sua vida a nos mostrar a importância da Arte na Educação. Percebendo a dificuldade que seria a criação de um ensaio significativo que contemplasse o tempo e o espaço é que ficamos somente a abrir janelas! As janelas compartilhadas com artistas, pesquisadores e arte educadores adquiriram horizontes com linhas sinuosas, hibridizadas, que, por vezes passaram ao som, nos levando da visão à audição, e, do som, conseguimos atingir também o aroma! Talvez os artistas surrealistas tenham também aberto janelas! Pois, é certo que com Magritte nós conseguimos sentir o cheiro do mar, e, com Max Ernst, tocamos a textura da terra. Mas, é somente com João Jardim que passamos a buscar a "Janela da alma"! E, é dessa forma que alguns vão orientar o seu olhar no ensaio em que homenageamos a Barbosa. Alguns caminhos da construção do olhar se darão de dentro para fora, outros de fora para dentro, e, é nesse vai e vem da construção dos percursos em que os sentidos vão multiplicando as janelas. Ana Mae Barbosa tem criado novas janelas e também tem nos levado a construir novas miradas. Com o GEARTE tentamos encontrar o tom, o tempo certo da grandeza de uma vida que sabe dar valor ao sonho no compasso da realidade de seu país.
\end{abstract}

PALAVRAS-CHAVE

Imagem poetizada. Horizonte da mirada. Linha sinuosa e hibridizada. Janela do olhar. Janela da alma.

ABSTRACT - Visual Essay: With how many windows? Tribute to Ana Mae Barbosa - We tried to pay a tribute to Ana Mae Barbosa using the poetics of her own image in action, but this is not an easy effort, especially, considering she has dedicated her life to show us the importance of the Art in the Education. Then we only tried to open some windows, because we saw the difficulty that would be the creation of a significant essay with the time and the space included. These windows shared with artists, researchers and art educators acquired artistic horizons with sinuous lines. Sometimes one hibridization happens where we can hear to the sound of the lines, taking to the sound from the vision and then also we can achieve the aroma! Perhaps, the surrealist artists have also open windows! Yes, it is true that with Magritte we can smell the ocean and with Max Ernst touch the texture of the earth. But, only with João Jardim is that we start to search the "window to the soul". Thus, in this way is that some people would like to guide their look in the essay in which we honour Barbosa. Some paths of the eyesight will be constructed looking from the inside out, others from outside to inside. In this comes and goes of construction of the paths is where the senses will multiply the windows. Ana Mae Barbosa has created new windows and, also has taken us to build new glances. We tried to find the tone with the GEARTE and perceive the correct time of the greatness of a life that knows how to give value to the dream in the rhythm of the reality of our country.

\section{KEYWORDS}

Poetized image. Horizon of the look. Winding and hybridized line. Window of the look. Window of the soul. 

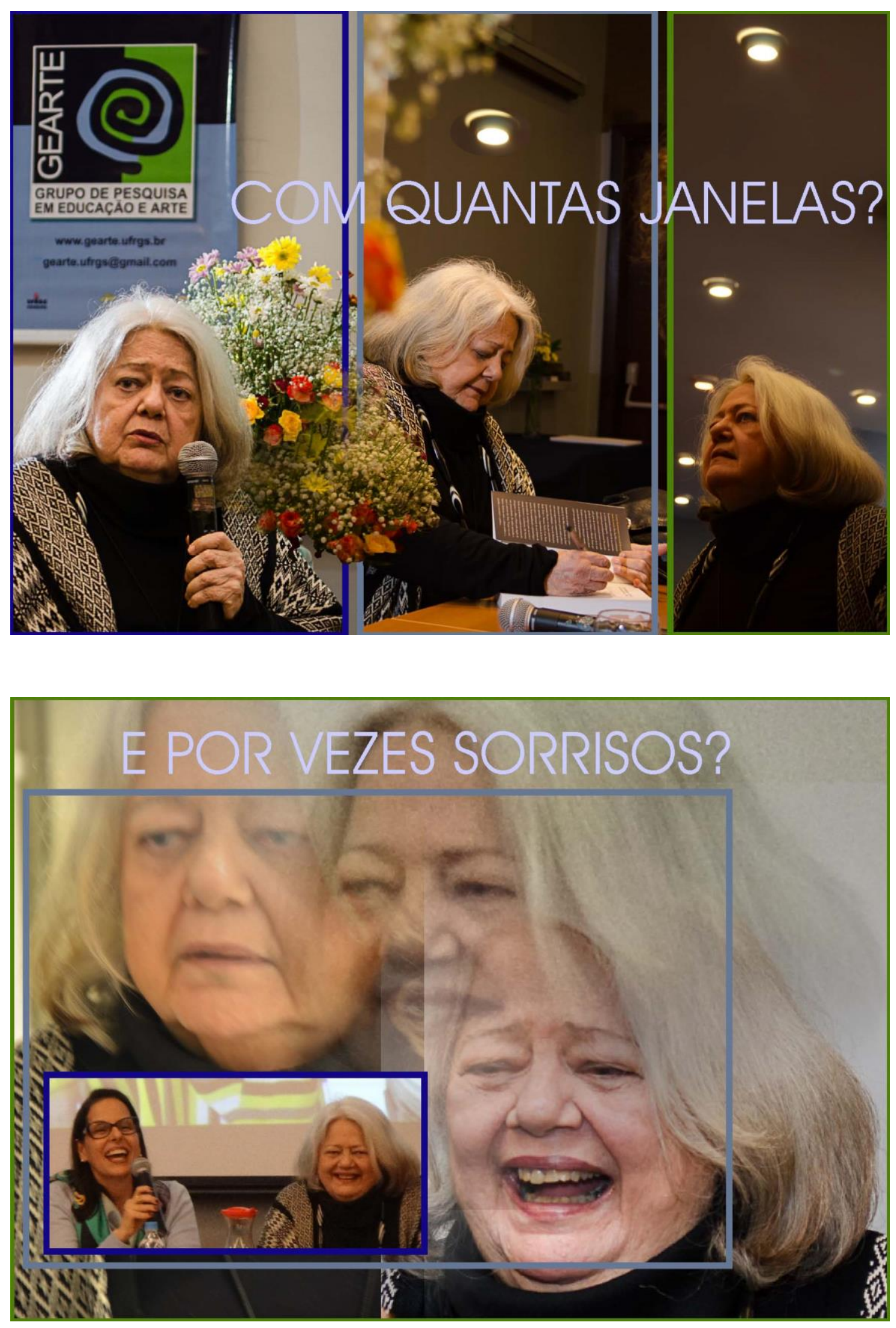

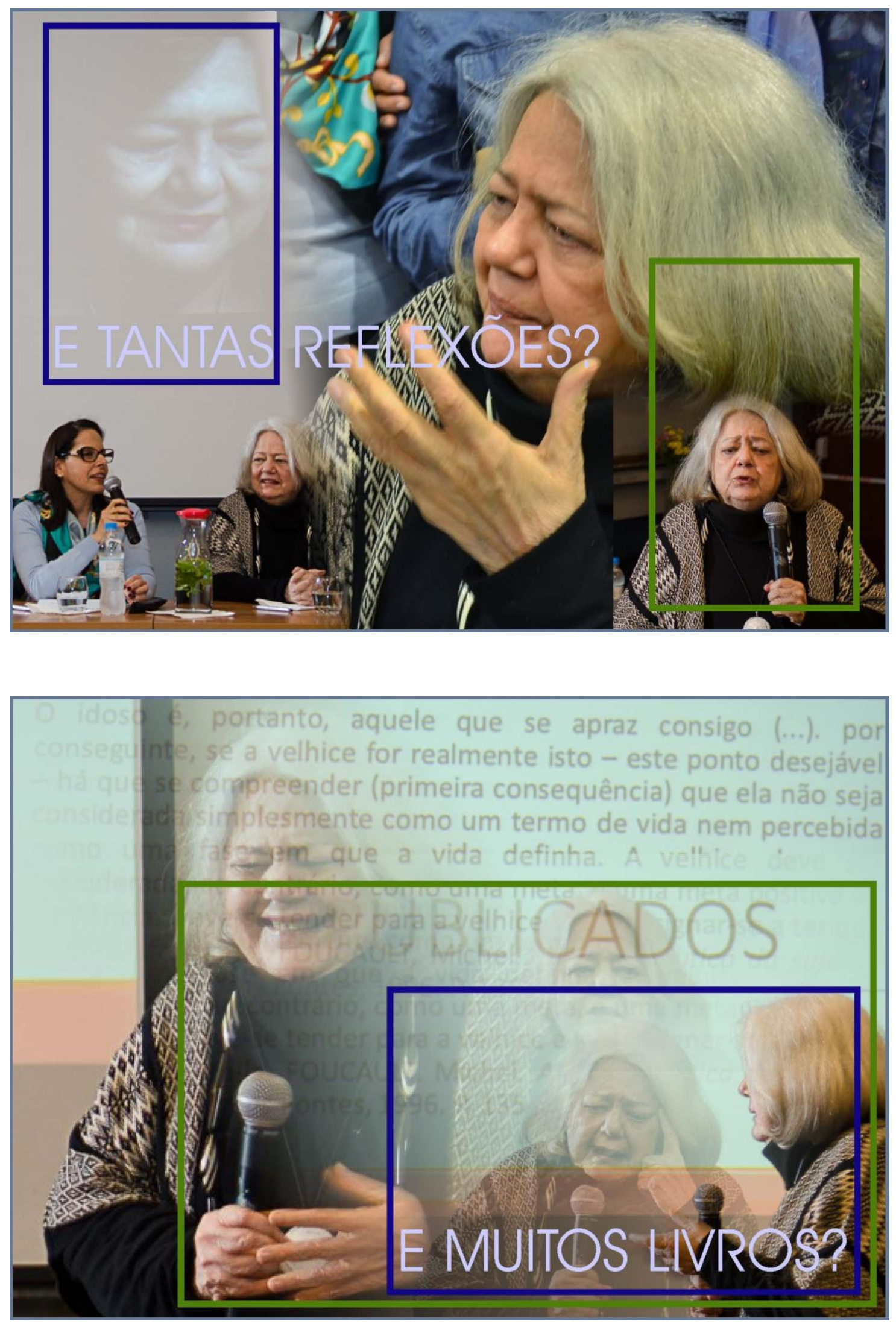

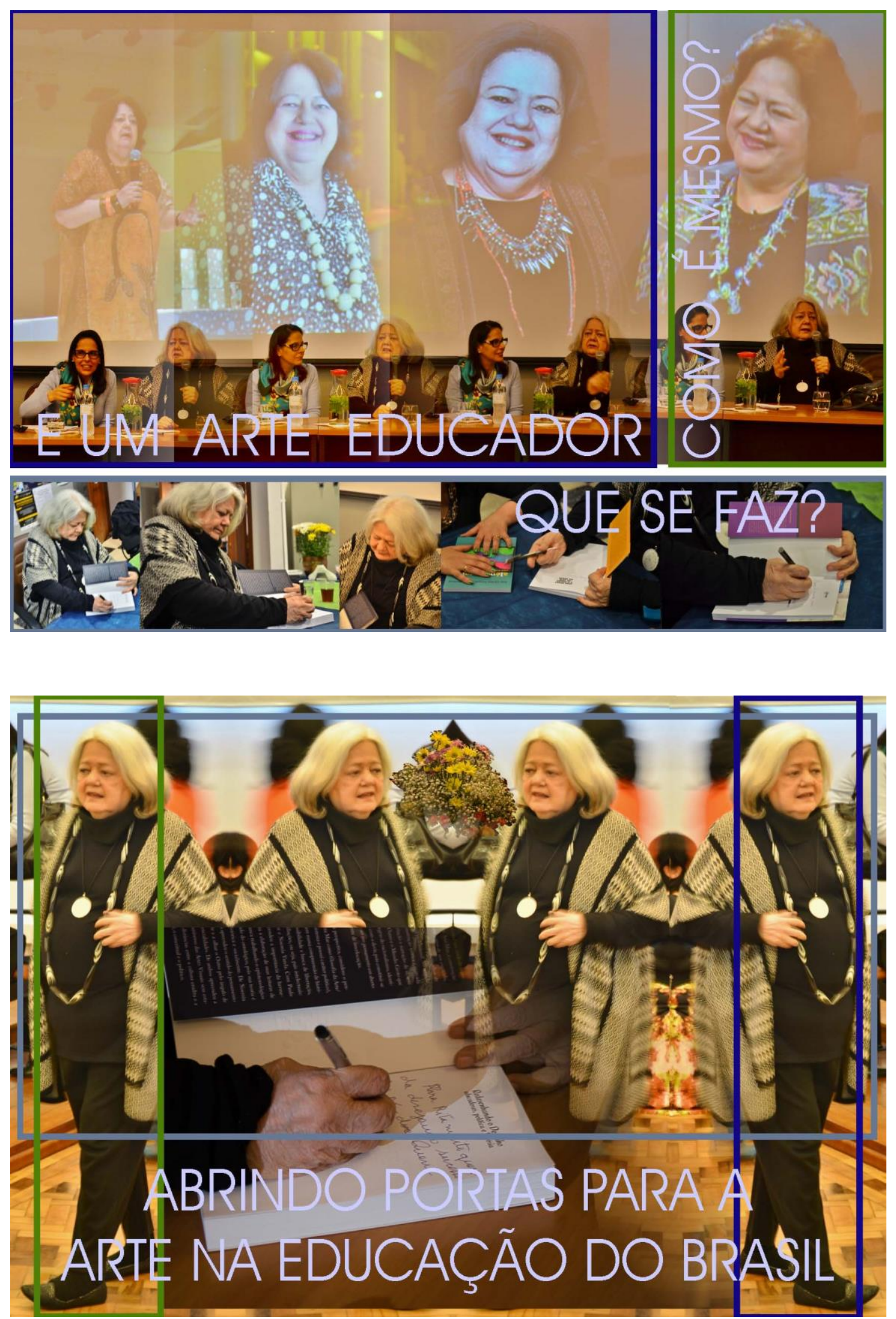


\section{COLOCANDO A ARTE EDUCAÇÃO BRASILEIRA}
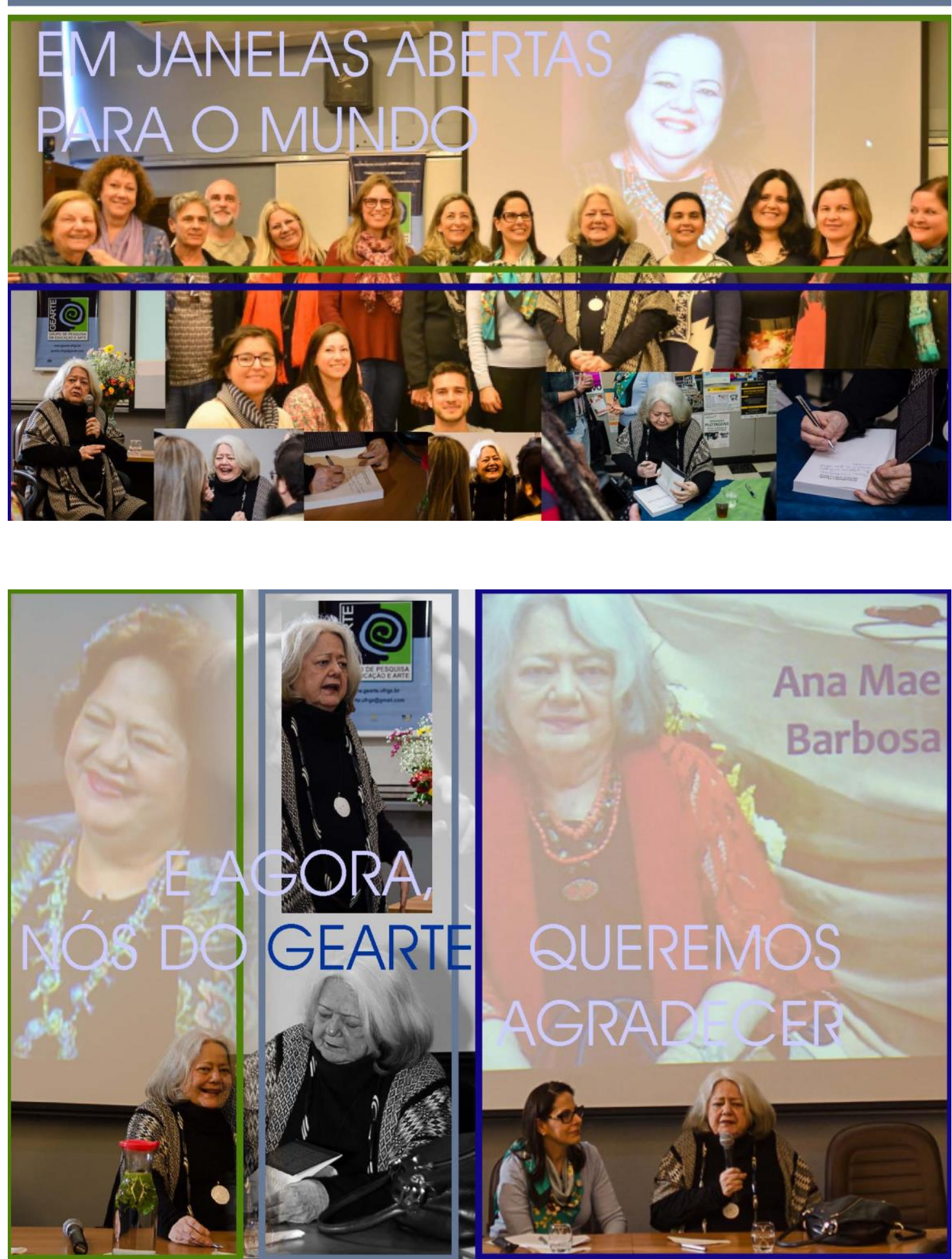

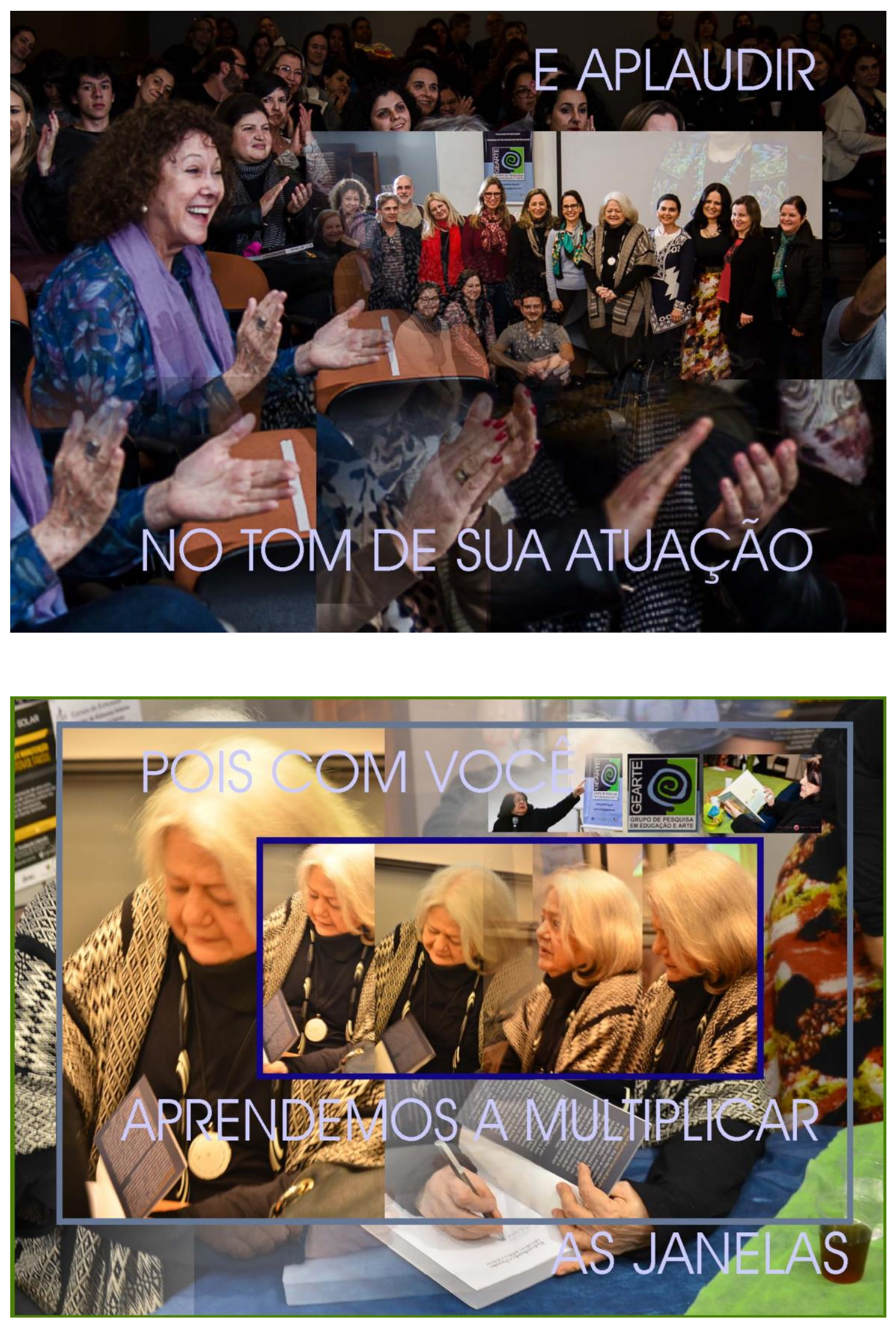


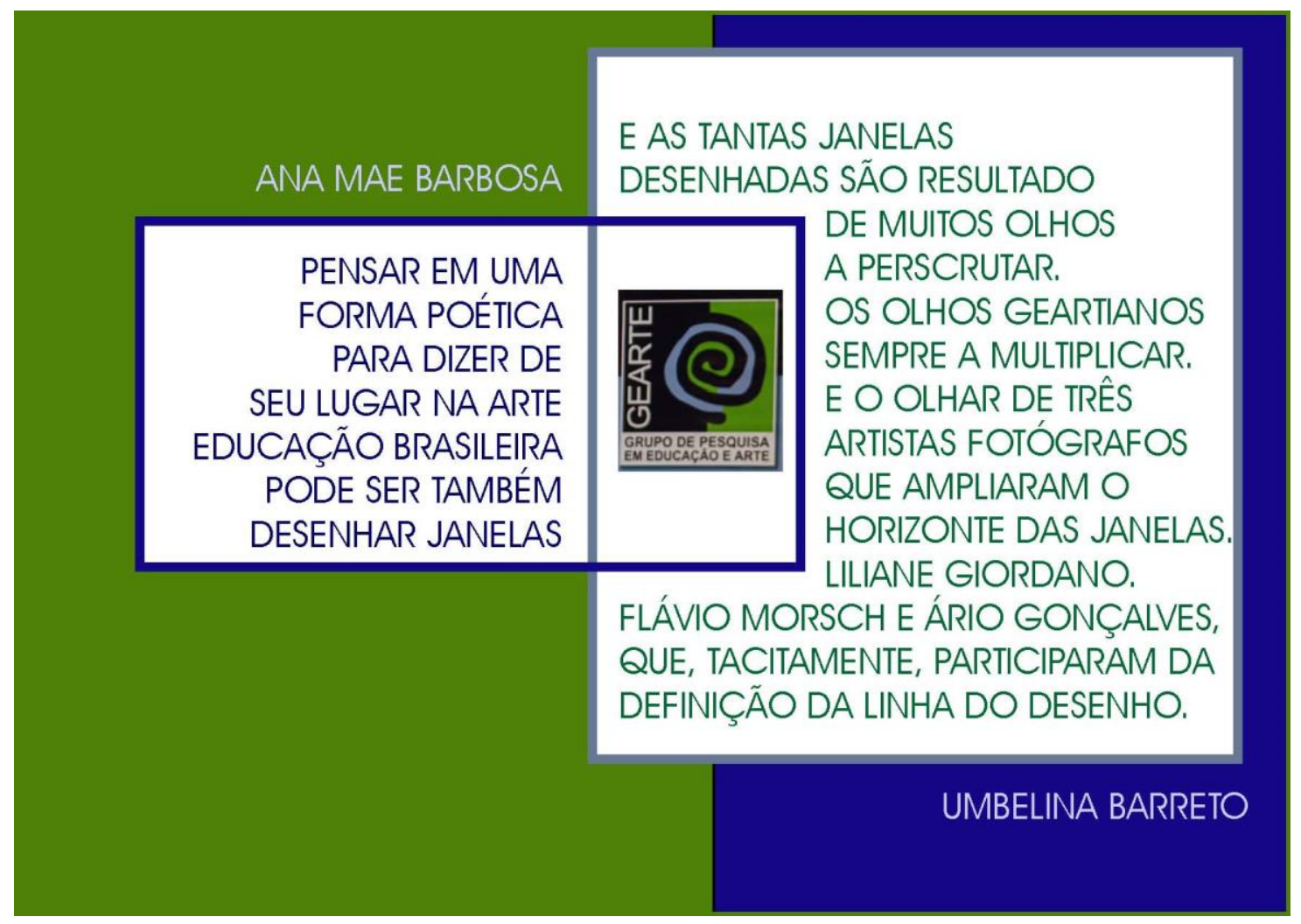

\section{Umbelina Barreto}

Graduação em Artes Plásticas/ Habilitação Desenho e Pintura - UFRGS (1978), Mestrado em Filosofia - PUCRS (1994) e Doutorado em Educação - UFRGS (2008). Professora Associada, nível I, do Instituto de Artes da UFRGS. Membro do Grupo de Pesquisa em Educação e Arte (GEARTE) - PPGEDU da Faculdade de Educação da UFRGS. Possui experiência na área de Artes Visuais com ênfase em Desenho e Pintura, e tem realizado produção regular em poéticas visuais, além de exposições no Brasil e no Exterior. Na pesquisa tem atuado, principalmente, nos seguintes temas: Ensino e Pesquisa da Linguagem do Desenho e Ensino e Pesquisa em Semiótica Discursiva. Tem realizado pesquisas na área de Semiótica, Filosofia da Arte e Epistemologia da Arte.

E-mail: umbelina.barreto@ufrgs.br

Currículo: http://lattes.cnpq.br/5596431631660931

Recebido em 06 de novembro de 2016 Aceito em 21 de dezembro de 2016 